\title{
トレーサーガスを用いた新鮮空気量充足度の推定実験
}

シリンダー八ウスにおける検証

\section{PRESUMPTION EXPERIMENT OF SUPPLY RATE FULFILLMENT USING TRACER GAS \\ Verification on the cylinder house}

\author{
田島昌樹*1, 澤地孝男*2, 瀬戸裕直*3, 武田 仁*4 \\ Masaki TAJIMA, Takao SAWACHI, Hironao SETO \\ and Hitoshi TAKEDA
}

\begin{abstract}
The purpose of this study is to estimate the accuracy of SRF (Supply Rate Fulfillment) value using tracer gas methods, which are constant concentration method and constant injection method, on the test house. The test house is established in an artificial climatic chamber, its air tightness can be varied and airflow rate can be known by $\Delta \mathrm{P}$ method which uses the differential of pressure between outside and rooms. Using SRF as a ventilation performance index, properties given by tracer gas are compared to their values given by network model or $\Delta \mathrm{P}$ method. The following are conclusions on the experiment in nearly steady conditions.

1. The ways to calculate and to treat SRF and other properties are shown.

2. The SRF values, which indicate less than 1.0 , are shown by using the tracer gas method.

3. SRF, $\alpha$ and other properties using tracer gas method can be indicated moderate value compare to other method.

4. The tracer gas method is useful to presume SRF value from practical standpoint.
\end{abstract}

Keywords: ventilation performance, tracer gas, constant concentration method, constant injection method, network model, house 換気性能 トレーサーガス 一定濃度法 一定発生法 換気回路網 住宅

1. はじめに

一般に住宅は多数の室が連続的に接続されており、ある室の換 気性状や換気性能を考える場合、他室を通過した空気の影響を無視 できない場合が多い。特に第 3 種型の換気システムや 2 階建住宅に おける温度差を利用した自然換気システムを導入している場合は直 接的に当該室に外気が導入されるのではなく他室を通過して当該室 に流入する空気の中に新鮮空気としてのポテンシャルを見出して換 気に供することも多く、このような他室を通過した空気の影響は相 対的に小さくはない。本研究は 2 階建実験住宅に、温度差換気と第 3

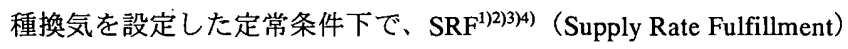
を換気性能評価指標に用いてトレーサーガスによる同指標や余剩新 鮮空気量率 $\alpha$ などの特性值の算定を行い、換気回路網による理論計算 や差圧法（後述する微差圧計を用いる方法）を用いて推定した場合 と比較し、実住宅での測定を視野に入れ測定手法の精度確認を行っ たものである。

\section{2. トレーサーガスによる換気性能の測定}

\section{1 既往の換気測定法}

トレーサーガスを使用した換気性状および換気性能の測定は、特 に単一のトレーサーガスを使用する場合、その注入手法により分類
クすると以下のようになる。

\begin{tabular}{|ll|}
\hline (1) パルス注入法 & (Pulse injection method) \\
(2) 減衰法 & (Decay method) \\
(3) 一定発生法 & (Constant injection method) \\
(4) 一定濃度法 & (Constant concentration method) \\
\hline
\end{tabular}

(1)は空気踰測定のためのパルス発生法や室間空気流量を推定する ための奥山のシステム同定法 5)などが代表的である。(2)は空気栯を 測定するためのステップダウン法や住宅の換気量測定法として JIS ${ }^{6}$ に定められており厳密には換気回数の測定法である。(3)の一定発生 法 Constant injection method ${ }^{799)}$ は Constant emission method ${ }^{8)}$ とも呼ばれ、 換気性状が変動しない条件で主に単室の換気量注 1)を求める手法で、 このような条件下で換気量を求める場合はは対象室の容積の影響を 考慮しないでよい。また換気システムの給気ダクトなどに同様の発 生法を用いてステップアップ法による空気齢測定が行われており上 述のステップダウン法と併せた測定事例 ${ }^{10111}$ はわが国でも多い。(4) は住戸内各室のトレーサーガス濃度を均一にするため室間の空気流 量は把握できないが、多数の室がある場合でも各室に直接供給され る外気導入量が測定でき、換気性状が変動する場合でも比較的安定 して測定が行える。また多種のガスを用いる方法では室間の換気量

\footnotetext{
*1 東京理科大学大学院理工学研究科建築学専攻 博士後期誅程・工修

*2 独立行政法人建築研究所上摩研究員・工博

*3 独立行政法人建築研究所 主任研究員

Graduate Student, Tokyo University of Science, M. Eng.

Building Research Institute, Dr. Eng.

Building Research Institute

Prof., Tokyo University of Science, Dr. Eng.
} 


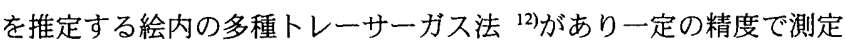
できることが確認されている。

\section{2 本研究で用いた手法}

本研究では、測定手法の複雑さや測定デー夕の処理に特別専門的 な知識を必要としない比較的簡単な測定手法を用いて換気性能を求 めることを目的とし、住宅の外気導入量を測定する手法として一定 濃度法注2)を、さらに換気性能評価指標 SRF 值を推定する手法として 一定発生法を採用した。なお本研究では一定発生法とは上記 Constant injection method のように換気量や空気齢の測定を目的としたもので はなくその収束濃度から対象室が充足状態にあるかどうかを判断し SRF 値を算定するために各室で異なる量のトレーサーガスを一定発 生させるものである。

\section{3. 換気性能評価手法}

\section{1 既往の研究における換気性能評価}

換気性能評価に関する既往研究は換気効率に関してなされている

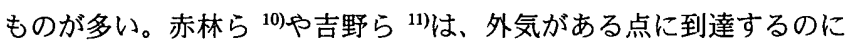
要する平均的な時間を表す局所空気齢を用い、名目換気時間で除し て基準化した局所空気交換効率により建築空間内の導入外気の分配 に着目した評価を行っている。また空気が有している污染物質の希 积能力に注目した換気性能指標として、加藤ら ${ }^{13) 14) か ゙ ~ C F D に よ り 才 ~}$ フィス空間などを対象に検討を行ったパージングフローレイト ${ }^{15) か ゙ ~}$ あげられる。パージングフローレイトは特に瞬時一様拡散場でない 污染質の濃度分布が存在する条件で、対象とした局所領域内で発生 する污染質量を当該対象領域の平均污染質濃度で除した值として表 され、局所領域の污染質濃度を定める実質的な換気量を示している。

一方、本研究で用いた SRF は多数室間の空気流動が有する污染質 の希釈能力を考慮に入れた対象空間の換気性能を示す指標であり上 記指標とは異なり、瞬時一様拡散の仮定のもとで使用される。

\section{2 新鮮空気量充足度 SRF}

換気性能評価指標として SRF 指標を用いることで以下のような利 点がある。

・各室および住宅全体の換気性能を 1 つの数字で示すことができ、 様々な換気システムを簡単に比較評価できる。

・当該指標の数字を比較することで適切な換気システムの選定に 用いることが出来る。

・各室に流入する空気量に含まれる新鮮外気としてのポテンシャ ルに着目し各室に供給される実質の新鮮空気量が評価できる。

また外気を含めた室間の空気流量が既知の場合、SRF 值は以下の 手順により算定できる。各室において必要新鮮空気量 $P_{i}$ を設定し、 室数だけたてられる新鮮空気の保存に関する式(1)を連立方程式とし て解き、各室の余剩新鮮空気量 $\alpha_{i}$ を求める。次に、式(2)によって算 出される各室の有効新鮮空気量 $S_{i}$ を式(3)に代入し算出される。式(3) の最初の等式にあるように、SRF は有効新鮮空気量と必要新鮮空気 量の比であり完全な充足状態で 1.0 を示す。なお SRF は他室を通過 した空気が污染物質を希釈する能力がある場合はそのポテンシャル を新鮮空気として、逆に污染物質濃度が高い場合はそのポテンシャ ルを負の新鮮空気として扱うことができる。実務における換気計画
では必要新鮮空気量 $P_{i}$ の設定が重要になるが通常は在室人数から算 定される空気量や次世代省エネルギー基準の新鮮空気の供給量の目 標値 ${ }^{16)}$ などをもとに決定する。また住宅全体の換気性能を表す指標 OSRF(Overall Supply Rate Fulfillment)を式(4)のように定義する。

$$
\begin{aligned}
& A_{i}+\sum_{j=1}^{n_{i}} \alpha_{j} \cdot Q_{i j}-\alpha_{i} \cdot\left(\sum_{j=1}^{m_{i}} Q_{j i}+B_{i}\right)-P_{i}=0 \\
& S_{i}=A_{i}+\sum_{j=1}^{n_{i}} \max \left(0, \alpha_{j} \cdot Q_{i j}\right)-\sum_{j=1}^{m_{i}} \max \left(0, \alpha_{i} \cdot Q_{j i}\right)-\max \left(0, \alpha_{i} \cdot B_{i}\right) \\
& S R F_{i}=\frac{S_{i}}{P_{i}-\sum_{j=1}^{n_{i}} \min \left(0, \alpha_{j} \cdot Q_{i j}\right)} \frac{S_{i}}{P_{i}^{\prime}} \\
& O S R F_{i}=\left(S R F_{1} \times S R F_{2} \times S R F_{3} \times \cdots \times S R F_{N}\right)^{1 / N} \\
& A_{i} \quad: i \text { 室への直接新鮮空気量 } \mathrm{m}^{3} / \mathrm{h} \\
& B_{i} \quad: i \text { 室から直接外部へ排出される空気量 } \mathrm{m}^{3} / \mathrm{h} \\
& \mathrm{N} \quad: \text { 必要新鮮空気量を設定した室数 } \\
& P_{i} \quad: i \text { 至の必要新鮮空気量 } \mathrm{m}^{3} / \mathrm{h} \\
& P_{i}^{\prime} \quad: i \text { 室の実質必要新鮮空気量 } \mathrm{m}^{3} / \mathrm{h} \\
& Q_{i j} \quad: j \text { 室から } i \text { 室へ流れる空気量 } \mathrm{m}^{3} / \mathrm{h} \\
& S_{i} \quad: i \text { 室の有効新鮮空気量 } \mathrm{m}^{3} / \mathrm{h} \\
& m_{i} \quad: i \text { 室から流出する空気の先となる室数 } \\
& n_{i} \quad: i \text { 室へ流入する空気の元となる室数 } \\
& \alpha_{i} \quad: i \text { 室の余剩新鮮空気量率 }
\end{aligned}
$$

\begin{tabular}{|c|c|c|c|c|}
\hline & SRF & $\alpha$ & 室間空気流量 & 外気導入量 \\
\hline 一定発生法 & $\triangle$ & 0 & $\triangle$ & $\Delta$ \\
\hline 一定濃度法 & $x$ & $x$ & $\times$ & 0 \\
\hline 換気回路網 & 0 & 0 & 0 & 0 \\
\hline 差压法* & 0 & 0 & 0 & 0 \\
\hline
\end{tabular}

3.3 トレーサーガスー定発生法による SRF の推定方法

表 1 に本研究で用いた換気性能および換気量予測・算定手法をま とめる。表 1 中の「○」はその手法のみで各項目が求められること を、「口」は一定の条件下で求められることを、「メ」はその手法の みでは求められない項目を示している。なお差圧法は各室間や外壁 に存在する隙間特性が完全に把握されている場合のみ有効な手法で 室内外や室間の差圧を微差圧計柱3)などを用いて測定することで、室 間空気流量を求める手法である。本研究では一定濃度法と一定発生 法を用いるため室間空気流量を完全に把握するには至らず、式(1)〜 式(3)を解く手法では SRF を算定することはできないが、トレーサー ガスの収束濃度などから一定条件下で SRFが求められる。

表 1 換気性能および換気量予測・算定手法

*シリンダーハウスのように隙間の位置と特性が既知である場合のみ可能

一定発生法を用いて SRF を算定する場合式(5)のように許容濃度を 定義し、式(6)のように各室のトレーサーガス発生量 $q_{i}$ の比が必要新 鮮空気量 $P_{i}$ の比と等しくなるように設定する。その結果すべての室 で許容濃度 $\sigma_{c}$ が等しくなり設定した必要新鮮空気量 $P_{i}$ に対して充足 （SRF=1）もしくは非充足（SRF<1）であるかがわかる。図 1 を用い て例示する。図 1 は A〜D の 4 室で一定発生法を行った場合のトレ 一サーガス濃度変化を模したものであり、トレーサーガス注入開始 後十分時間が経過しガス濃度が収束した状態で、許容濃度 $\sigma_{c}$ を上回 つている室が非充足状態にあることを示す。つまり許容濃度が $\sigma_{c(3)}$ と して決められた場合は A 室および B 室が $\mathrm{SRF}=1$ の充足状態にあり、 $\mathrm{C}$ 室および $\mathrm{D}$ 室が非充足状態 $\mathrm{SRF}<1$ となる。また、許容濃度が $\sigma_{\text {c1 }}$ や $\sigma_{\mathrm{c}(2)}$ である場合には、全室が許容濃度を下回り $\mathrm{SRF}=1$ となる。 


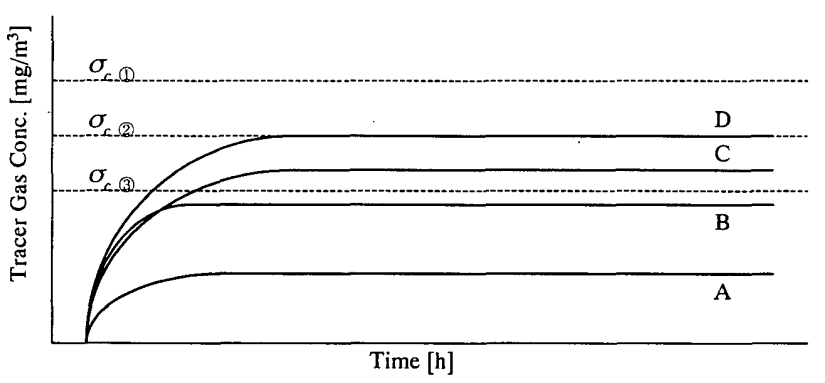

図 1 一定発生法による収束濃度と許容濃度の例

既往の研究 ${ }^{3)}$ では $S R F<1$ の条件では、充足か非充足かの判断を行 うことのみにこの手法を使用していたため SRF の算定は行っていな かったが本研究では、以下のような方法で算定を行った。余剩新鮮 空気量率 $\alpha_{i}$ 之許容濃度 $\sigma_{c}$ および収束濃度 $\sigma_{i}$ はその定義から式(7)の関 係にあり式(9)の $i$ 室に流入する空気の平均的な余剩新鮮空気量率 $\bar{\alpha}_{i}$ が分かれば、式(8)で定義した濃度比 $d_{i}$ および式(10)によって SRF 值 が算定できる。トレーサーガスの測定結果のみで $\bar{\alpha}_{i}$ を算定するには 空気の流入元となる室数が外気を含めて 2 室までとする限定条件が つけられるが、多くの居室ではこの条件になると考えられる。各室 の濃度推移と換気量およびトレーサーガスの発生量は式(11)の関係 にあり、収束状態では式(11)’のように左辺が 0 となり、測定結果か ら各室のトレーサーガス濃度 $\left(C_{i} 、 C_{j}\right)$ および一定濃度法により外気 導入量 $A_{i}$ の值が得られるため室間空気流量 $Q_{i j}$ もしくは空気流入のも ととなる室からの室間空気流量の比が算定できる。よって式(9)から 和が求められ、SRFが算定できる。また $\mathrm{SRF}_{\mathrm{i}}$ は式(3)に示したように i 室の有効新鮮空気量の実質必要新鮮空気量に対する比であるので、 式(12)のように当該室に不足する外気相当空気量が算定でき、SRF<1 を示した室の換気性能改善に必要な空気量を知ることができる。

$$
\begin{aligned}
& \sigma_{c}=\frac{q_{i}}{P_{i}} \\
& P_{1}: P_{2}: P_{3}: \cdots: P_{n}=q_{1}: q_{2}: q_{3}: \cdots: q_{n} \\
& 1-\frac{\sigma_{i}}{\sigma_{c}}=\alpha_{i} \\
& d_{i}=\frac{\sigma_{c}}{\sigma_{i}} \\
& \bar{\alpha}_{i}=\frac{A_{i}+\sum_{j=1}^{\mathrm{N}} \max \left(0, \alpha_{j} \cdot Q_{i j}\right)}{A_{i}+\sum_{j=1}^{\mathrm{N}} Q_{i j}}
\end{aligned}
$$

$$
S R F_{i}=d_{i} \cdot \frac{1}{d_{i}+\left(1-d_{i}\right) \cdot \frac{1}{\bar{\alpha}_{i}}}
$$$$
\frac{d C_{i}}{d t} V=q_{i}+\sum_{j=1}^{n_{i}} Q_{i j}\left(C_{j}-C_{i}\right)-A_{i} C_{i}
$$$$
0=q_{i}+\sum_{j=1}^{n_{i}} Q_{i j}\left(C_{j}-C_{i}\right)-A_{i} C_{i}
$$$$
Q_{L i}=\left(1-S R F_{i}\right) \cdot P_{i}^{\prime}
$$

$C_{i} \quad: i$ 室のトレーサーガス濃度 $\mathrm{mg} / \mathrm{m}^{3}$

$Q_{L i} \quad: i$ 室の不足する外気相当空気量 $\mathrm{m}^{3} / \mathrm{h}$

$d_{i} \quad: i$ 室における濃度比

$q_{i} \quad: i$ 室のトレーサーガス発生量 $\mathrm{mg} / \mathrm{h}$ $\bar{\alpha}_{i} \quad: i$ 室に流入する空気の平均余剩新鮮空気量率

$\sigma_{c} \quad:$ 許容濃度 $\mathrm{mg} / \mathrm{m}^{3}$

$\sigma_{i} \quad: i$ 室の収束濃度 $\mathrm{mg} / \mathrm{m}^{3}$

4. シリンダーハウスにおける実験

4.1 実験概要

測定精度検証のための実験は建築研究所の人工気候室内に設置さ れたシリンダーハウス ${ }^{4)}$ (図 2 および図 3）において行った。シリン ダーハウスは図 3 のようにシリンダーが外壁面に多数設置されてお り気密性能が自由に設定できる他、屋外条件となる人工気候室やシ リンダーハウス内部の温度を自由に設定できる。実験に用いたシリ ンダー等の隙間特性を表 2 に示す。また実験に先立ち当該建物の気 密測定を行ったところ建物全体で相当隙間面積が $7.2\left[\mathrm{~cm}^{2}\right]$ 、相当隙間 面積が $0.1\left[\mathrm{~cm}^{2} / \mathrm{m}^{2}\right]$ を示し、外壁部にはほとんど隙間のない状態であ った。また人工気候室内は $400\left[\mathrm{~m}^{3} / \mathrm{min}\right]$ の風量で換気されておりシリ ンダーハウスからトレーサーガスが排出された場合でもガス濃度が あがらないようになっている。トレーサーガスの注入や採取はシリ ンダーハウスや人工気候室とは別室となる制御室に設置した INNOVA 製のトレーサーガスモニター社4)を使用した。当該測定器に ガス搬送のためのチューブを接続し図 2 中の $\times$ 印部分（高さは天井 高の半分）にてガスの注入および採取を行い、注入口前面にはカス が十分拡散するように小型ファンを設置した。なお本研究ではトレ 一サーガスとして $\mathrm{SF}_{6}$ を用いた。
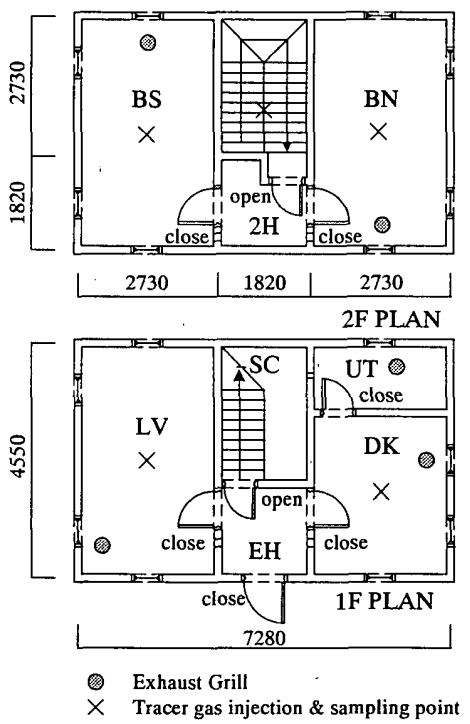

因 3 シリンダーハウス平面図および設定

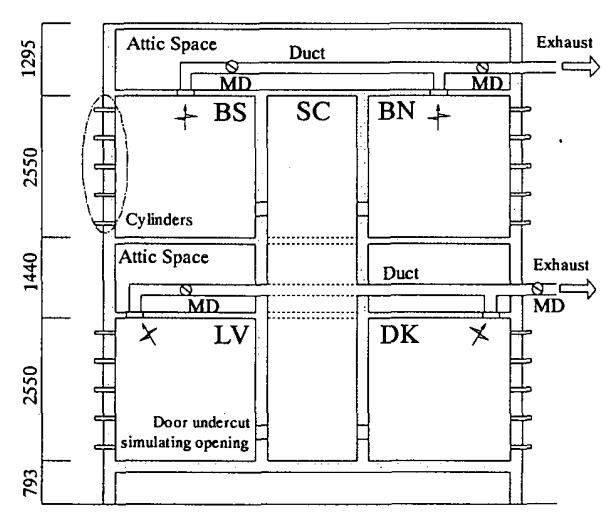

図 4 シリンダーハウス断面図 
実験条件を表 3 に、換気システムの形態を図 4 に、各室に設定し た必要新鮮空気量の設定值を表 4 に示す。本研究は他室を通過する 空気についての評価值推定を目的としているため、排気を居室で行 うほか温度差換気が併用されるよう設定した。室内外温度は $1^{\circ} \mathrm{C}$ 末満 程度の変動で制御され、排気風量は図 3 の天井裏および小屋裏内の ダクト内風速を測定することによりモーターダンパー（MD）を制御 して風量を一定に保つようになっており、超音波流量計で更正した 熱線式風量計などで調整を行い $\pm 2\left[\mathrm{~m}^{3} / \mathrm{h}\right]$ 程度住 5$)$ の誤差範囲で設定し た。またドアアンダーカットを模した室間の開口は文献 ${ }^{13)}$ を参考に $\alpha A=136\left[\mathrm{~cm}^{2}\right]$ と設定した。

表 2 隙間および開口条件

\begin{tabular}{r|c|c}
\hline 開口形状 & $\alpha A\left[\mathrm{~cm}^{2}\right]$ & $n$ \\
\hline シリンター (流入) & 15.3 & 2.0 \\
(流出) & 15.6 & 2.0 \\
スリット (流入) & 1.47 & 1.28 \\
(流出) & 1.55 & 1.25 \\
\hline トアアアタターカット $\mathbf{1 6 0}$ & 136.0 & 2.0 \\
\hline
\end{tabular}

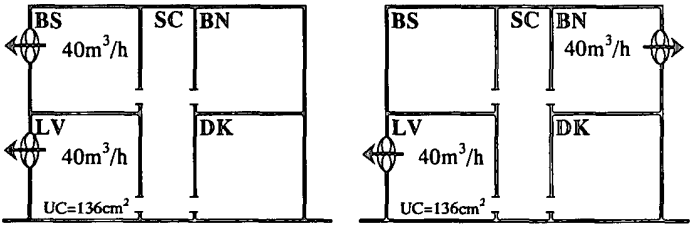

図 4 機械換気形態（左をシステム $\mathrm{a}$ 、右をシステム $\mathrm{b}$ とする） ダクト式のシステムであるが機械排気を壁付けファンで示した

表 3 実験条件

\begin{tabular}{|c|c|c|c|c|c|}
\hline \multirow{2}{*}{$\begin{array}{l}\text { 実験 } \\
\text { CASE }\end{array}$} & \multirow{2}{*}{$\begin{array}{l}\text { 換気 } \\
\text { システム }\end{array}$} & \multirow{2}{*}{$\begin{array}{c}\text { 相当隙間面積* } \\
{\left[\mathrm{cm}^{2} / \mathrm{m}^{2}\right]}\end{array}$} & \multicolumn{3}{|c|}{ 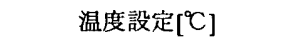 } \\
\hline & & & 屋外 & 室内 & 温度差 \\
\hline 01 & $\mathrm{a}$ & 5 & 5 & 20 & 15 \\
\hline 02 & b & $\uparrow$ & $\uparrow$ & $\uparrow$ & $\uparrow$ \\
\hline 03 & a & 2 & $\uparrow$ & $\hat{\imath}$ & $\uparrow$ \\
\hline 04 & b & $\uparrow$ & $\uparrow$ & $\uparrow$ & $\uparrow$ \\
\hline
\end{tabular}

表 4 各室の必要新鮮空気量設定値

\begin{tabular}{c|c|c|c|c|c}
\hline & $\mathrm{LV}$ & $\mathrm{DK}$ & $\mathrm{BS}$ & $\mathrm{BN}$ & $\mathrm{SC}$ \\
\hline$P_{i}\left[\mathrm{~m}^{3} / \mathrm{h}\right]$ & 40 & 20 & 20 & 40 & 0 \\
\hline
\end{tabular}

\section{2 他手法との比較方法}

上述のようにトレーサーガスを用いた手法により得られた結果を、 差圧法や換気回路網と比較することで精度を確認した。これら比較 対照とした手法は表 2 の隙間特性を用いて室間空気流量を算定する ことで室数分の余剩新鮮空気量率 $\alpha_{i}$ に関する連立方程式（式(1)）を 解き SRF 等の換気性能特性值を算出した。ただし差圧法では室間差 压が小さく空気流量に誤差が生じやすいので、外壁から流出入する 空気量のみを算定し、系が閒じるように SC で空気量の調整を行った。 また機械排気風量は設定値として固定した。

\section{3 実験および計算結果と考察}

一定発生法によるトレーサーガスの発生量と濃度推移の例を図 5 に示す。この CASE では BN 室の換気風量がほとんど得られなかっ たため濃度収束までに最も時間がかかった。全ての CASE で図 5 の ように収束するまでトレーサーガスによる測定を継続し収束後 1 時 間以上のデータを採取し SRF 等の特性值を算定した。
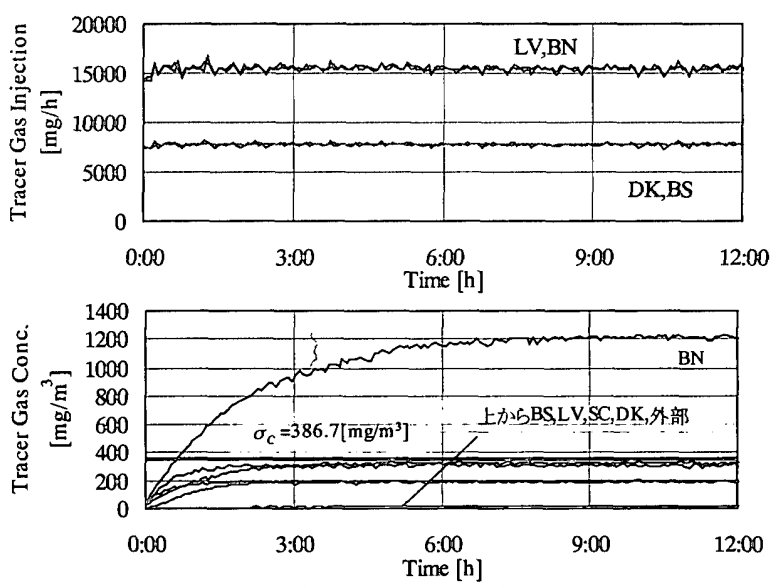

図 5 CASE01 トレーサーガス発生量および濃度推移（一定発生法）

本研究では換気回路網による計算結果を理論的な正解値と考え、 差圧法による推定は微差圧計の精度や僅かに生じていると考えられ る温度ムラおよびシリンダーハウス外壁に僅かに存在する隙間など の影響による推定誤差を含む準正解值と考え、トレーサーガス法に よる推定值がこれらの値とどの程度乘離しているかを基準に比較を 行った。

\section{（1）直接外気導入量および室間空気流量}

住宅の換気性能評価において直接外気導入量は最も基本的な指標 である。また SRF の算定には各室の直接外気導入量が既知となれば 推定精度が高くなるため本研究では一定濃度法を用いて各室の外気 導入量を測定した。実験および回路網計算によって得られた各室の 外気導入量を図 6 に、シリンダーハウス全体の換気量を表 5 に示す。 また換気回路網計算と差圧法によって得られた室間空気流量を図 7 および図 8 に示す。トレーサーガス法と示してあるものは、一定浱 度法によって得られた数值である。すべての手法において外気導入 量に大きな差異はなく、また図 7 および図 8 のように差圧法と回路 網計算で室間の空気流動も比較的一致しており、各手法で同様の換 気性状が示されている結果を得た。
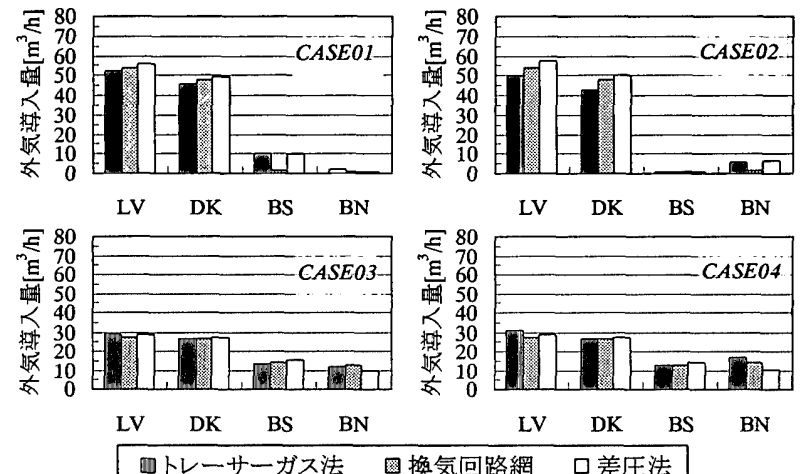

四トレーサーガス法 圈換気回路網 口差圧法

図 6 各室の外気導入量比較

表 5 シリンダーハウス全体換気量 $\left[\mathrm{m}^{3} / \mathrm{h}\right]$

\begin{tabular}{c|c|c|c}
\hline CASE & トレーサーガス法 & 換気回路網 & 差圧法 \\
\hline 01 & 111.2 & 104.2 & 116.5 \\
\hline 02 & 98.9 & 104.2 & 115.2 \\
\hline 03 & 80.2 & 79.8 & 80.8 \\
\hline 04 & 86.7 & 79.8 & 80.1 \\
\hline
\end{tabular}



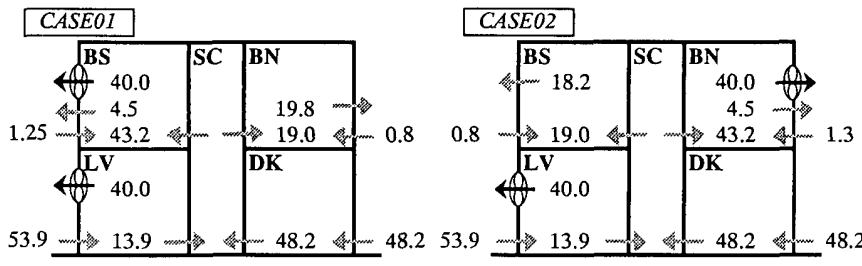

CASE03

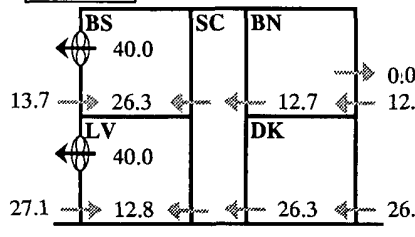

CASE04

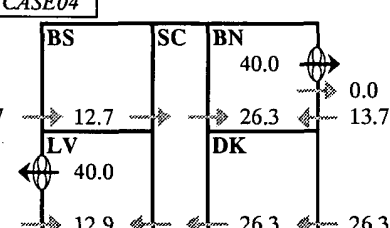

図 7 換気回路網計算による換気性状

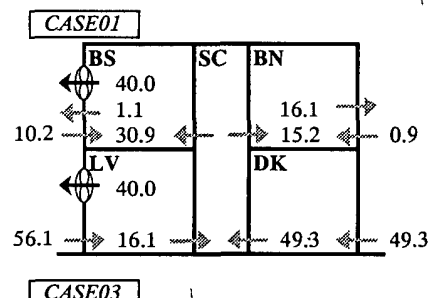

CASE02

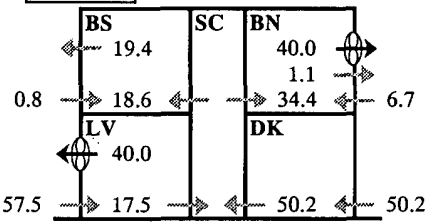

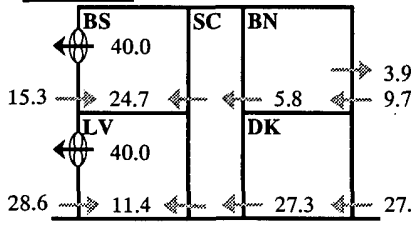

CASE04

図 8 差圧法による換気性状

\section{(2) SRF および $\alpha$ 算定値}

トレーサーガス法による SRF 算定値を表 6〜9 および図 9 に示す。 また各手法による SRF と $\alpha$ を表 10１3 に示す。表 6〜9で各 CASE の許容濃度が異なっているのは測定時のガスボンべ圧などによりガ スの供給量が異なっていたためである。また表 6〜13 では SRF<1 お よび $\alpha<0$ の部分をグレーに、またそのうち居室で最も SRF が低い室 は黒く塗りつぶした。図 9 のように各 CASE で充足状態の室が変化 に富んだ結果となっている。各手法で SRF、 $\alpha$ とも非常に近い值を示 しているほか各 CASE で室ごとの傾向が一致している。一部 CASE04 の SC において換気回路網による值が他手法と比較して若干低い值 を示した以外は、 $\mathrm{SRF}=1$ もしくは SRF<1（充足もしくは非充足）に ついても一致した。なお換気回路網による当該部分 (CASE04 の SC) は $\alpha$ 值が他手法と同様 0 に近く、SRF值もほぼ一致していると言える。

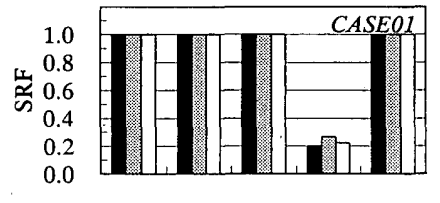

LV DK BS BN SC

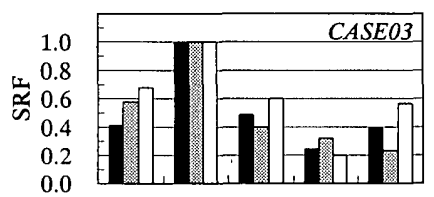

LV DK BS BN SC ロトレーサーガス法 圆換気回路網 口差圧法

図 9 各手法による SRF 值比較
表 6 ・トレーサーガス法による SRF（CASE01）

\begin{tabular}{c|c|c:c:c:c:c}
\hline & $P_{\mathrm{i}}\left[\mathrm{m}^{3} / \mathrm{h}\right]$ & $\sigma_{\mathrm{c}}\left[\mathrm{mg} / \mathrm{m}^{3}\right]$ & $\sigma_{\mathrm{i}}\left[\mathrm{mg} / \mathrm{m}^{3}\right]$ & $d_{\mathrm{i}}$ & $\alpha_{\mathrm{i}}$ & $\mathrm{SRF}_{\mathrm{i}}$ \\
\hline $\mathrm{LV}$ & 40 & 307.5 & 1.26 & 0.20 & 1.00 \\
\hline $\mathrm{DK}$ & 20 & & 187.1 & 2.07 & 0.52 & 1.00 \\
\hline $\mathrm{BS}$ & 20 & 386.7 & 325.6 & 1.19 & 0.16 & 1.00 \\
\hline $\mathrm{BN}$ & 40 & & 1208.3 & 0.32 & .2 .12 & 0.21 \\
$\mathrm{SC}$ & 0 & & 199.0 & 1.94 & 0.49 & 1.00 \\
\hline
\end{tabular}

表 7 トレーサーガス法による SRF（CASE02）

\begin{tabular}{c|c|c|c:c:c:c}
\hline & $P_{\mathrm{i}}\left[\mathrm{m}^{3} / \mathrm{h}\right]$ & $\sigma_{\mathrm{c}}\left[\mathrm{mg} / \mathrm{m}^{3}\right]$ & $\sigma_{\mathrm{i}}\left[\mathrm{mg} / \mathrm{m}^{3}\right]$ & $d_{\mathrm{i}}$ & $\alpha_{\mathrm{i}}$ & $\mathrm{SRF}_{\mathrm{i}}$ \\
\hline $\mathrm{LV}$ & 40 & & 307.5 & 1.30 & 0.23 & 1.00 \\
\hline $\mathrm{DK}$ & 20 & & 187.1 & 2.14 & 0.53 & 1.00 \\
\hline $\mathrm{BS}$ & 20 & 388.2 & 325.6 & 0.53 & -0.88 & 0.38 \\
$\mathrm{BN}$ & 40 & & 1208.3 & 0.78 & -0.27 & 0.67 \\
\hline $\mathrm{SC}$ & 0 & & 199.0 & 2.01 & 0.50 & 1.00 \\
\hline
\end{tabular}

表 8 トレーサーガス法による SRF（CASE03）

\begin{tabular}{c|c|c|c|c|c|c}
\hline & $P_{\mathrm{i}}\left[\mathrm{m}^{3} / \mathrm{h}\right]$ & $\sigma_{\mathrm{c}}\left[\mathrm{mg} / \mathrm{m}^{3}\right]$ & $\sigma_{\mathrm{i}}\left[\mathrm{mg} / \mathrm{m}^{3}\right]$ & $d_{\mathrm{i}}$ & $\alpha_{\mathrm{i}}$ & $\mathrm{SRF}$ \\
\hline $\mathrm{LV}$ & 40 & & 307.5 & 0.72 & -0.38 & 0.72 \\
\hline $\mathrm{DK}$ & 20 & & 187.1 & 1.16 & 0.14 & 1.00 \\
\hline BS & 20 & 351.1 & 325.6 & 0.67 & 0.50 & 0.67 \\
\hline BN & 40 & & 1208.3 & 0.35 & -1.86 & 0.26 \\
\hline $\mathrm{SC}$ & 0 & & 199.0 & 0.76 & -0.31 & 0.25 \\
\hline
\end{tabular}

表 9 トレーサーガス法による SRF（CASE04）

\begin{tabular}{c|c|c|c:c:c:c}
\hline & $P_{\mathrm{i}}\left[\mathrm{m}^{3} / \mathrm{h}\right]$ & $\sigma_{\mathrm{c}}\left[\mathrm{mg} / \mathrm{m}^{3}\right]$ & $\sigma_{\mathrm{i}}\left[\mathrm{mg} / \mathrm{m}^{3}\right]$ & $d_{\mathrm{i}}$ & $\alpha_{\mathrm{i}}$ & $\mathrm{SRF} F_{\mathrm{i}}$ \\
\hline $\mathrm{LV}$ & 40 & & 307.5 & 0.91 & 0.10 & 0.87 \\
\hline DK & 20 & & 187.1 & 1.33 & 0.25 & 1.00 \\
\hline BS & 20 & 389.6 & 325.6 & 0.79 & 0.26 & 0.73 \\
\hline BN & 40 & & 1208.3 & 0.72 & -0.39 & 0.56 \\
\hline SC & 0 & & 199.0 & 1.26 & 0.21 & 1.00 \\
\hline
\end{tabular}

表 10 各手法による SRF 值比較（CASE01）

\begin{tabular}{c|c|c|c|c|c|c}
\hline & \multicolumn{2}{|c|}{ トレーサーガス法 } & \multicolumn{2}{|c|}{ 換気回路網 } & \multicolumn{2}{|c}{ 差压法 } \\
\cline { 2 - 7 } & $\mathrm{SRF}_{\mathrm{i}}$ & $\alpha_{\mathrm{i}}$ & $\mathrm{SRF}_{\mathrm{i}}$ & $\alpha_{\mathrm{i}}$ & $\mathrm{SRF}_{\mathrm{i}}$ & $\alpha_{\mathrm{i}}$ \\
\hline $\mathrm{LV}$ & 1.00 & 0.20 & 1.00 & 0.26 & 1.00 & 0.29 \\
\hline $\mathrm{DK}$ & 1.00 & 0.52 & 1.00 & 0.58 & 1.00 & 0.59 \\
\hline $\mathrm{BS}$ & 1.00 & 0.16 & 1.00 & 0.07 & 1.00 & 0.15 \\
\hline $\mathrm{BN}$ & 0.21 & -2.12 & 0.26 & -1.49 & 0.22 & -1.94 \\
$\mathrm{SC}$ & 1.00 & 0.49 & 1.00 & 0.51 & 1.00 & 0.52 \\
\hline
\end{tabular}

表 11 各手法による SRF 值比較（CASE02）

\begin{tabular}{|c|c|c|c|c|c|c|}
\hline & \multicolumn{2}{|c|}{ トレーサーガス法 } & \multicolumn{2}{|c|}{ 換気回路網 } & \multicolumn{2}{|c|}{ 差圧法 } \\
\hline & $\mathrm{SRF}_{\mathrm{i}}$ & $\alpha_{\mathrm{i}}$ & $\mathrm{SRF}_{\mathrm{i}}$ & $\alpha_{i}$ & $S R F_{i}$ & $\alpha_{i}$ \\
\hline LV & 1.00 & 0.23 & 1.00 & 0.26 & 1.00 & 0.30 \\
\hline DK & 1.00 & 0.53 & .1 .00 & 0.58 & 1.00 & 0.60 \\
\hline BS & 0.38 & -0.88 & 0.52 & -0.48 & 0.19 & -0.49 \\
\hline $\mathrm{BN}$ & 0.67 & 0.27 & 0.58 & 0.37 & 0.62 & 0.37 \\
\hline SC & 1.00 & 0.50 & 1.00 & 0.51 & 1.00 & 0.52 \\
\hline
\end{tabular}

表 12 各手法による SRF 值比較（CASE03）

\begin{tabular}{|c|c|c|c|c|c|c|}
\hline & \multicolumn{2}{|c|}{ トレーサーガス法 } & \multicolumn{2}{|c|}{ 換気回路網 } & \multicolumn{2}{|c|}{ 差圧法 } \\
\hline & $\mathrm{SRF}_{\mathrm{i}}$ & $\alpha_{i}$ & $\mathrm{SRF}_{\mathrm{i}}$ & $\alpha_{\mathrm{i}}$ & $\mathrm{SRF}_{\mathrm{i}}$ & $\alpha_{\mathrm{i}}$ \\
\hline LV & 0.72 & 0.38 & 0.58 & -0.49 & 0.67 & -0.35 \\
\hline DK & 1.00 & 0.14 & 1.00 & 0.24 & 1.00 & 0.27 \\
\hline BS & 0.67 & 0.50 & 0.40 & .0 .51 & 0.60 & -0.25 \\
\hline $\mathrm{BN}$ & 0.26 & -1.86 & 0.32 & -2.14 & 0.21 & -3.14 \\
\hline SC & 0.25 & 0.31 & 0.23 & 0.54 & 0.57 & 0.22 \\
\hline
\end{tabular}

表 13 各手法による SRF 值比較（CASE04）

\begin{tabular}{c|c|c|c|c|c|c}
\hline & トレーサーガス法 & \multicolumn{2}{|c|}{ 換気回路網 } & \multicolumn{2}{|c|}{ 差法 } \\
\hline & $\mathrm{SRF}_{\mathrm{i}}$ & $\alpha_{\mathrm{i}}$ & $\mathrm{SRF}_{\mathrm{i}}$ & $\alpha_{\mathrm{i}}$ & $\mathrm{SRF}_{\mathrm{i}}$ & $\alpha_{\mathrm{i}}$ \\
\hline $\mathrm{LV}$ & 0.87 & 0.10 & 0.67 & -0.33 & 0.74 & -0.20 \\
\hline $\mathrm{DK}$ & 1.00 & 0.25 & 1.00 & 0.24 & 1.00 & 0.27 \\
\hline $\mathrm{BS}$ & 0.73 & -0.26 & 0.63 & 0.57 & 0.70 & 0.43 \\
\hline $\mathrm{BN}$ & 0.56 & -0.39 & 0.34 & -0.67 & 0.34 & -0.61 \\
$\mathrm{SC}$ & 1.00 & 0.21 & 0.86 & -0.03 & 1.00 & 0.10 \\
\hline
\end{tabular}

\section{（3）トレーサーガス法を基準とした他手法の特性値比較}

図 10 に外気導入量 $A_{i}$ 、余唾新鮮空気量率 $\alpha_{i} 、$ SRF および不足する 外気相当空気量 $Q_{L i}$ についてトレーサーガス法と他種法を比較した 散布困を示す。また表 14 に差圧法および換気回路網により算定され た各特性值からトレーサーガス法による算定值を差し引いて得られ た差を各室の条件ごとに整理したものを示す。表 14 では回路網とト 


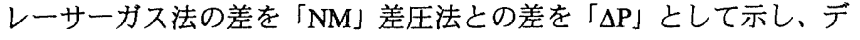
一夕分類条件では空気流動の上流室（外気は含まない）数と $\mathrm{SRF}<1$ について分類した。図 10 では各数值とも相関が高く回路網や差圧法 と近い值を示しており $\mathrm{SRF}_{\mathrm{i}}$ や $Q_{L}$ は各手法で若干のばらつきが見ら れるが、 $Q_{L i}$ の数值の差自体は大きくはない。また表 14 では、当該 室がどのような条件でも各手法の平均的な差は大きくないことがわ かる。トレーサーガス法が他手法と比較して一定の精度を持ち、実 用上問題が無いと考えられる。

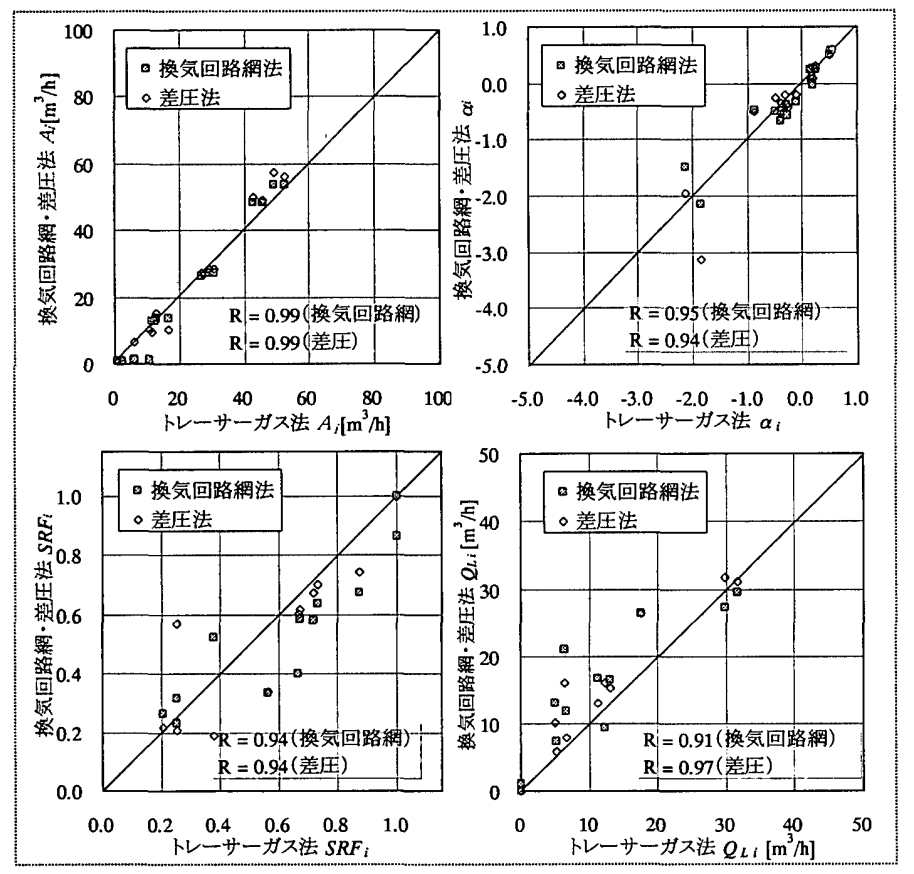

図 10 各手法特性值比較散布図

表 14 トレーサーガス法を基準とした他種法の特性值差

\begin{tabular}{|c|c|c|c|c|c|c|c|}
\hline \multirow{2}{*}{\multicolumn{2}{|c|}{$\begin{array}{l}\text { データ分類条件 } \\
(\mathrm{n}=\overline{\text { テ }} \text {-夕数 })\end{array}$}} & \multicolumn{2}{|c|}{$S R F_{i}$} & \multicolumn{2}{|c|}{$\alpha_{i}$} & \multicolumn{2}{|c|}{$Q_{L i}$} \\
\hline & & \multirow{2}{*}{$\frac{N M}{-0.05}$} & \multirow{2}{*}{$\frac{\Delta \mathrm{P}}{-0.02}$} & \multirow{2}{*}{$\frac{N M}{-0.03}$} & \multirow{2}{*}{$\frac{\Delta P}{-0.03}$} & \multirow{2}{*}{$\frac{\mathrm{NM}}{2.08}$} & \multirow{2}{*}{$\frac{\Delta P}{1.77}$} \\
\hline 全データ & 平均 & & & & & & \\
\hline$(n=20)$ & s.d. & 0.10 & 0.10 & 0.23 & 0.33 & 4.29 & 3.00 \\
\hline \multirow{2}{*}{$\begin{array}{c}\text { 上流室数 : } 1 \\
(\mathrm{n}=7)\end{array}$} & 平均 & -0.09 & -0.09 & 0.03 & 0.05 & 3.32 & 2.86 \\
\hline & s.d. & 0.14 & 0.09 & 0.32 & 0.20 & 4.52 & 3.07 \\
\hline \multirow{2}{*}{$\begin{array}{c}\text { 上流室数 : } 2 \\
(n=4)\end{array}$} & 平均 & -0.04 & 0.08 & -0.11 & 0.01 & 3.90 & 2.47 \\
\hline & s.d. & 0.07 & 0.16 & 0.14 & 0.08 & 7.15 & 4.93 \\
\hline \multirow{3}{*}{$\begin{array}{l}\text { SRF }<1 \\
(\mathrm{n}=10) \\
\end{array}$} & 平均 & -0.08 & -0.05 & -0.05 & -0.09 & 2.61 & 2.56 \\
\hline & s.d. & 0.14 & 0.15 & 0.32 & 0.46 & 4.38 & 2.80 \\
\hline & \multicolumn{7}{|c|}{$\begin{array}{l}\mathrm{NM}: \text { 回路網(Network Model)とトレーサーガス法の差 } \\
\Delta \mathbf{P}: \text { 差压法とトレーサーガス法の差 } \\
\text { s.d. : 棒準偏差 }\end{array}$} \\
\hline
\end{tabular}

\section{5. おわりに}

本研究では SRF を換気性能評価指標とし、トレーサーガスを用い た同指標の算定手法や関連する指標の関係式や導出方法を示した。 またシリンダーハウスにおいてほぼ定常的な条件を設定し SRF 值や その他特性值の推定実験を行い換気回路網計算や差圧法により算定 された同指標との比較を行い以下のような結果を得た。

(1) トレーサーガスを用いた一定発生法および一定濃度法により $\mathrm{SRF}<1$ 条件での SRF 值の算出を行い、換気回路網による理論計 算や差圧法により算出された值と比較して平均的差は 0.1 以内 にありほぼ正確な值であることを確認した。

(2) SRF 值や他の換気性能をあらわす特性值から算出される各室の
不足する外気相当空気量 $Q_{L i}$ の算出を行い、他手法により算出 された値と比較して大きな誤差の無いことを確認した。

(3) トレーサーガス法は一定の精度を有しており、定常的条件では 実用上問題がないと考えられる。

本研究の手法を用いることで他室を通過した空気の新鮮空気とし てのポテンシャルを評価できるため実住宅における換気性能評価に 有効であると考える。本研究により実験室における SRF 推定のため のトレーサーガス法の精度が確認されたので、フィールドでの非定 常的な条件における同測定手法の適用を試みる予定である。

\section{謝辞}

本研究を行うにあたり、日本工業大学の成田健一教授およびジェ イベック(株)の石橋誠司氏（研究当時日本工業大学研究生）の多大な る協力を得ました。記して謝意を表します。

注

本論文は口頭発表したもの ${ }^{18) 19)}$ を精查し再編集したものである。

注1）一定発生法では多数室の換気も扱えるが、換気性状が変動す るような条件下では測定デー夕から換気量に変換する際の平 均化作業が室容積などの影響が大きく室ごとに換気量を算出 するための平均時間に差が生じる。

注2）一定濃度法はトレーサーガスの濃度制御が複雑ではあるが本 研究で使用した機材は比較的正確かつ容易に自動制御により 測定ができる。

注3）測定レンジは $1 \operatorname{Torr}(133.322 \mathrm{~Pa}$ )で分解能は 0.01\%F.S. 精度は $0.15 \%$ である。

注4）トレーサーガス濃度検知部の性能は検出限界が $10 \mathrm{ppb}$ 1ppm ダイナミックレンジが通常検出限界の 100,000 倍である。本 研究では主に 5ppm〜50ppm 程度の範囲で測定を行った。ま た本論文では濃度は重量濃度で表示した。

注5） シリンダーハウスの室間のドアアンダーカット模擬開ロを閉 鎖し各室を単室として設定し、シリンダーの数を調整し室内 外差圧を測定している微差圧計の誤差およびシリンダー以外 に極僅かに存在する隙間が影響しない程度の圧力条件を当該 排気システムによって作り出し、シリンダーを通過する風量 の合計＝排気システムから排気される風量とみなした実験結 果やトレーサーガスを用いた減衰法（室容積は内法寸法とし 室内に設置された測定器などの容積を把握できる範囲で考慮 した）などと比較をしてこの程度の精度にあることを確認し た。

\section{参考文献}

1) 澤地孝男 瀬戸裕直 大西茂樹 谷口佳紀 大澤元毅 : 住宅用換 気システムの換気性能評価に関する研究その 10 換気性能評価 指標 OVRF の検討, 日本建築学会大会学術講演梗概集 D2, pp645-646, 1996.9

2）澤地孝男 瀬戸裕直 大澤元毅 : 住宅用換気システムの換気性能 評価に関する研究 その $11 \sim 12$, 日本建築学会大会学術講演梗概 集 D2, pp607-610，1997.9

3）澤地孝男 瀬戸裕直 : 住宅用換気システムの換気性能評価に関す る研究 その 13 トレーサーガスー定発生法を用いた各種換気 システムの評価事例, 日本建築学会大会学術講演梗概集 D2, pp553-554, 1998.9

4) Shigeki Ohnishi Takao Sawachi Yoshinori Taniguchi Haruki Ohsawa Hironao Seto : A New Experimental Approach for the Evaluation of Domestic Ventilation Systems Part3 - Evaluation of Ventilation Systems for an Entire House, ASHRAE Transactions : Research, pp598-61, 1998

5) 奥山博康 澤地孝男 瀬戸裕直 大西由哲：トレーサーガスを用 いた換気性状把握手法の検証と改良（その 2) 検証実験の結果， 空気調和・衛生工学会学術講演会講演論文集, pp437-440, 1997

6) JIS A1406 ${ }^{1974}$ 屋内換気量測定方法（炭酸ガス法），2001.6

7) Claude -Alain Roulet, Luk Vandaele : Technical Note AIVC34 Air Flow Patterns within Buildings Measurement Techniques, Air 
Infiltration and Ventilation Centre, $\quad 1991.12$

8) Grieve P. W. : Measuring Ventilation using Tracer gases, Brüel \& Kjær, 1989.10

9) Allard Francis : Natural Ventilation in Buildings A Design Handbook, pp159-172, James \& James, 1998

10）たとえば赤林伸一 坂口涅 : 漏入空気の影響を考慮した換気効率 指標の算出方法 住宅の換気システムに関する研究その 2, 日本 建築学会計画系論文集 第 512 号, pp33-37, 1998.10

11）たとえば吉野博 長友宗重 小林仁:気密住宅における集中換気 システムの空気齢による性能測定，日本建築学会計画系論文集 第 464 号, pp57-64, 1994.10

12）絵内正道 澤地孝男 島田潔。福島史幸 瀬戸裕直 : 換気量既知 の実験住宅を用いた多種トレーサーガス法の検証, 日本建築学会 計画系論文集第 537 号, pp49-56, 2000.11

13) 加藤信介 : 数值流体力学 CFD の室内環境への灾用(6) CFD 解析 の実際 (その 2) 污染質・粉塵抎散, 空気調和・衛生工学会 第 71 巻 第 11 号, pp123-134, 1997.11

14）伊藤一秀 加藤信介 村上周三:平均拡散場解析による Visitation
Frequency, Purging Flow Rate の解析 不完全混合室内の居住域 換気効率の評価に関する研究，日本建築学会計画系論文集第 529 号, pp31-37, 2000.3

15) Etheridge David Sandberg Mats : Building Ventilation : Theory and Measurement, JHON WILEY \& SONS, pp259-262, 1996

16）次世代省エネルギー基準解説書編集委員会 : 住宅の次世代省エネ ルギー基準と指針，（財）IBEC，1999

17) 清水則夫 : 住宅部品の通気抵抗について, 空気調和·衛生工学会 学術講演会講演梗概集, pp609-612, 1995

18）田島昌樹 澤地孝男 瀬戸裕直 成田健一 武田仁 石橋誠 司：住宅の換気性能予測に関する研究 シリンダーハウスにおけ る検証実験, 空気調和・衛生工学会学術講演会講演論文集, pp573-576, 2001.9

19) 田島昌樹 澤地孝男 瀬戸裕直 津田学志 井前貴正 武田仁 内野徳弘：新鮮空気量の充足度指標を用いた換気システムの評価 実験 その 1 実験および評価方法概要, 日本建築学会大会学術 講演梗概集 D2, pp759-760, 2002.8 